\title{
Ефективність програми навчально-тренувального процесу юних легкоатлеток 13-14 років упродовж першого макроциклу річної підготовки (на прикладі спринтерського бігу)
}

\author{
Тетяна Маленюк \\ Вікторія Бабаліч \\ Галина Панченко \\ Олександр Брояковський
}

\author{
Центральноукраїнський державний педагогічний університет \\ імені Володимира Винниченка, \\ Кропивницький, Україна
}

Мета: розробити й довести ефективність програми тренувального процесу легкоатлеток-спринтерів упродовж першого макроциклу річної підготовки.

Матеріал і методи: до експерименту було залучено десять спортсменок 13-14 років, які тренуються у гуртку з легкої атлетики опорного навчального закладу. Використано наступні методи дослідження: теоретичний аналіз і узагальнення даних науково-методичної літератури, педагогічний експеримент, педагогічне тестування, методи математичної статистики.

Результати: визначено, що улегкоатлетів на етапі попередньої базової підготовки застосовується двоциклове планування річної підготовки («здвоєний» цикл). Розкрито структуру планування тренувального процесу у першому макроциклі: періоди, етапи, мезоцикли. Розроблено програму тренувального процесу легкоатлеток упродовж першого макроциклу «здвоєного» циклу річної підготовки.

Висновки: доведено ефективність програми тренувального процесу легкоатлеток на основі підвищення їх показників фізичної підготовленості та спортивних досягнень на змаганнях з легкоатлетичного двоборства.

Ключові слова: легка атлетика, програма, макроцикл, фізична підготовленість, юні спринтери.

\section{Вступ}

В. М. Платонов [11] сформулював основні завдання підготовки спортсменів на етапі попередньої базової підготовки: 1) різнобічний розвиток рухових здібностей, 2) зміцнення здоров'я, 3) усунення недоліків у рівні їх фізичного розвитку і фізичної підготовленості, 4) створення рухового потенціалу, що передбачає формування рухових навичок (що відповідають специфіці майбутньої спортивної спеціалізації), 5) формування стійкого інтересу спортсменів до спортивного удосконалення в обраному виді спорту.

У навчальній програмі з легкої атлетики для дЮСш зазначено, що технічна підготовка на етапі попередньої базової підготовки базується на різнобічному матеріалі виду спорту, обраному для спеціалізації спортсмена. Наприклад, у спринтерському бігу засвоюється техніка стартових вправ (старт з ходьби і повільного бігу, старт з падіння, з опорою на одну руку, низький старт у полегшених і ускладнених умовах), спеціальних бігових вправ, техніка бігу (рухи рук, ніг, положення тулуба, техніка дихання тощо), біг з перемінною швидкістю, спринтерський біг (гладкий біг, біг вгору, по піску тощо), техніка різноманітних стрибкових вправ, штовхання ядра й набивного м'яча [1]. у процесі фізичної підготовки юних спортсменів особливу увагу необхідно приділяти розвитку різних форм швидкості, а також швидкісно-силових, координаційних здібностей й гнучкості. Враховуючи високі темпи приросту вказаних рухових здібностей, недоречно планувати на даному етапі комплекси вправ з високою інтенсивністю і нетривалими паузами відпочинку, а також тренувальні заняття з великими навантаженнями [3].

Фахівцями з легкої атлетики [1] рекомендовано наступний розподіл співвідношення видів роботи різної переважної спрямованості на етапі попередньої базової підготовки, який представлено у таблиці 1.

У спортивному тренуванні юних легкоатлетів необхідно враховувати низку методичних і організаційних особливостей [12]:

1. тренувальні заняття не повинні бути орієнтовані на спортивні досягнення на етапах початкової і попередньої базової підготовки;

2. навантаження повинні відповідати функціональним можливостям біологічного стану організму спортсмена;

3. у тренувальному процесі необхідно дотримуватися раціонального режиму, забезпечувати побутову гігієну, належну організацію контролю 
Таблиця 1

Співвідношення видів спортивної підготовки легкоатлетів на етапі попередньої базової підготовки

\begin{tabular}{|c|c|c|c|c|c|}
\hline $\begin{array}{c}\text { Етап багаторічної } \\
\text { підготовки }\end{array}$ & 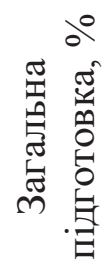 & 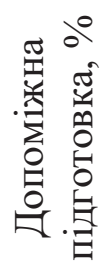 & 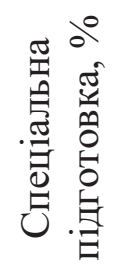 & 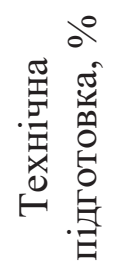 & 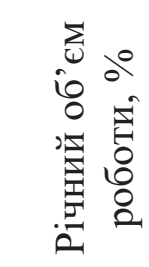 \\
\hline $\begin{array}{l}\text { Попередньої базової } \\
\text { підготовки }\end{array}$ & 40 & 30 & 15 & 15 & $250-600$ \\
\hline
\end{tabular}

за станом здоров'я і фізичним розвитком юного легкоатлета;

4. $з$ підвищенням рівня підготовленості легкоатлетів поступово зменшується відсоток засобів загальної фізичної підготовки і збільшується відсоток засобів спеціальної фізичної підготовки.

Науковці В. М. Платонов [11] і Л. П. Матвєєв [9] € основоположниками теорії побудови підготовки спортсменів у багаторічному процесі спортивного удосконалення. На їх думку, побудова річної підготовки може здійснюватися на основі одного макроциклу - одноциклова підготовка, двох - двоциклова, трьох - трьохциклова тощо. У кожному макроциклі виділяють періоди: підготовчий, змагальний і перехідний.

Водночас при багатоцикловій побудові тренувального процесу упродовж року використовують різні варіанти: «здвоєний», «строєний» тощо. Тому що перехідні періоди між першим і другим, другим і третім і т. д. макроциклами не плануються (Л. П. Матвєєв, 1977; В. М. Платонов. 1986).

Аналіз спеціальної літератури показав, що в юних легкоатлетів на етапі початкової та попередньої базової підготовки широко застосовується двоциклове планування річної підготовки [4; 7]. Перший макроцикл має базовий характер, передбачає комплексну підготовку і виступ на змаганнях, не наскільки відповідальних, як головні змагання року. Тренувальний процес у другому макроциклі набуває специфічного характеру, підготовка спрямована на вдалий виступ на головних змаганнях року [5; 8; 10].

Питання удосконалення фізичної підготовки юних легкоатлетів досліджували В. Добринський, Ж. Мудрик [6], О. Висоцька, В. Сергієнко [2] та інші.

Таким чином, питання структури та змісту двоциклового планування річної підготовки юних легкоатлетів на етапі попередньої базової підготовки у науковій та навчально-методичній літературі висвітлені недостатньо, що і обумовило вибір теми нашого дослідження.

Мета дослідження - побудова тренувального процесу у першому макроциклі двоциклової річної підготовки легкоатлеток-спринтерів 13-14 років до змагань 3 легкоатлетичного двоборства.

\section{Завдання дослідження:}

На основі аналізу науково-методичної літератури вивчити питання планування річної підготовки легкоатлетів-спринтерів на етапі попередньої базової підготовки.
Розробити програму підготовки легкоатлеток-спринтерів 13-14 років до змагань з легкоатлетичного двоборства упродовж першого макроциклу двоциклового планування річної підготовки і визначити її ефективність.

\section{Матеріал і методи дослідження}

у дослідженні брали участь десять спортсменок 13-14 років, які тренуються у гуртку з легкої атлетики опорного навчального закладу «Дмитрівської загальноосвітньої школи I-ІІІ ступенів імені Т. Г. Шевченка» Дмитрівської сільської ради Знам'янського району Кіровоградської області. Легкоатлетки спеціалізуються у бігу на 60 і 100 м, мають досвід спортивної підготовки 3-4 роки і спортивну кваліфікацію - III та II юнацький розряд з легкої атлетики.

Для вирішення завдань дослідження застосовувались наступні методи: аналіз наукової та навчально-методичної літератури, педагогічний експеримент, педагогічне тестування, методи математичної статистики.

\section{Результати дослідження}

У ході дослідження розроблено структуру планування тренувального процесу легкоатлеток-спринтерів у першому макроциклі двоциклової річної підготовки (табл. 2).

У структурі планування тренувального процесу легкоатлеток упродовж першого макроциклу двоциклової річної підготовки виділяють два періоди: підготовчий і зимовий змагальний, а також три етапи: загально-підготовчий (вересень-жовтень), спеціально-підготовчий (листопад) і змагальний (грудень). Отже, у легкоатлеток на етапі попередньої базової підготовки застосовується двоциклове планування річної підготовки («здвоєний» цикл). Тому що при двоцикловому плануванні річної підготовки між макроциклами відсутній перехідний період. Змагальний період першого макроциклу плавно переходить у підготовчий період наступного (Л. П. Матвєєв, 1977; В. М. Платонов. 1986).

Планування тренувального процесу в загально-підготовчому етапі передбачало два втягуючі мезоцикли. Завдання втягуючих мезоциклів - підвищення рівня загальної і допоміжної фізичної підготовленості, та функціональних можливостей систем організму легкоатлеток, зміцнення опорно-рухового апарату і спроможність спортсменок переносити навантаження, величина яких поступово зростає. По завершенню загально-підго- 
Таблиця 2

Структура планування тренувального процесу у першому макроциклі двоцикловї річної підготовки легкоатлеток 13-14 років

\begin{tabular}{|c|c|c|c|c|c|c|c|c|c|c|c|c|c|c|c|c|}
\hline \multicolumn{17}{|c|}{ Макроцикл } \\
\hline Періоди & \multicolumn{12}{|c|}{ Підготовчий } & \multicolumn{4}{|c|}{$\begin{array}{c}\text { Зимовий } \\
\text { змагальний }\end{array}$} \\
\hline Етапи & \multicolumn{8}{|c|}{ Загально-підготовчий } & \multicolumn{4}{|c|}{$\begin{array}{l}\text { Спеціально- } \\
\text { підготовчий }\end{array}$} & \multicolumn{4}{|c|}{ Змагальний } \\
\hline Мезоцикли & \multicolumn{4}{|c|}{ Втягуючий } & \multicolumn{4}{|c|}{ Втягуючий } & \multicolumn{4}{|c|}{ Базовий } & \multicolumn{4}{|c|}{ Змагальний } \\
\hline Місяці & \multicolumn{4}{|c|}{ Вересень } & \multicolumn{4}{|c|}{ Жовтень } & \multicolumn{4}{|c|}{ Листопад } & \multicolumn{4}{|c|}{ Грудень } \\
\hline Мікроцикли & B & B & B & $\mathrm{y}$ & B & B & Y & $\mathrm{y}$ & B & $\mathrm{y}$ & $\mathrm{y}$ & $\begin{array}{l}\text { В } \\
\text { Д }\end{array}$ & $\begin{array}{l}П \\
Д\end{array}$ & $\begin{array}{c}3 \\
M\end{array}$ & $\begin{array}{l}\text { В } \\
\text { Д }\end{array}$ & $\begin{array}{l}\text { В } \\
\text { Д }\end{array}$ \\
\hline Змагання, год. & & & & & & & & 2 & & & & & & 2 & & \\
\hline $\begin{array}{l}\text { Засоби } \\
\text { відновлення, } \\
\text { год. }\end{array}$ & & 2 & & 2 & & 2 & & 2 & & 2 & & 2 & & 2 & & 2 \\
\hline
\end{tabular}

Примітка:

В - втягуючий мікроцикл, У - ударний мікроцикл, ВД - відновний мікроцикл,

ПД - підвідний мікроцикл, ЗМ - змагальний мікроцикл

товчого етапу легкоатлети брали участь у відкритому Чемпіонаті Кіровоградської області з легкоатлетичного двоборства серед юнаків і дівчат 2005-2006 років народження з метою підвищення рівня їх тренованості та набуття змагального досвіду. До складу легкоатлетичного двоборства, в якому брали участь спортсменки, входить біг на 60 м з бар'єрами і гладкий біг на 60 м, а також біг на 60 м з бар'єрами і біг на 400 м.

Спеціально-підготовчий етап представлено базовим мезоциклом, що передбачає цілеспрямовану спеціальну підготовку за рахунок збільшення відсотку спеціально-підготовчих вправ, максимально наближених до змагальних.

Зимовий змагальний період представлений змагальним мезоциклом. Головним змаганням макроциклу був Чемпіонат Черкаської області $з$ легкоатлетичного двоборства серед юнаків і дівчат 2005-2006 років народження (7 грудня 2019 року, м. Черкаси).

Під час розробки програми навчально-тренувального процесу легкоатлеток упродовж першого макроциклу «здвоєного» річного циклу підготовки у гуртку 3 легкої атлетики, ми орієнтувались на навчальну програму з легкої атлетики для ДЮСШ. Так, легкоатлетки 1314 років першого року навчання на етапі попередньої базової підготовки відповідно до програми з легкої атлетики для ДЮСШ мають 12 годин тижневого навантаження (табл. 3) [1]. Водночас, легкоатлетки у гуртку 3 легкої атлетики при опорному навчальному закладі мають лише 8 годин тижневого навантаження.

Таблиця 3

Мінімальний вік спортсменів, мінімальна наповнюваність груп, тижневий режим навчально-тренувальної роботи з легкої атлетики на етапі попередньої базової підготовки у дюсш

\begin{tabular}{|c|c|c|c|c|c|}
\hline 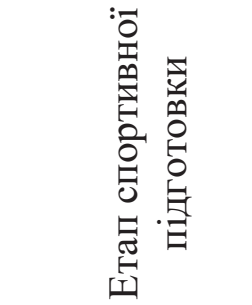 & 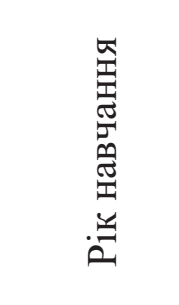 & 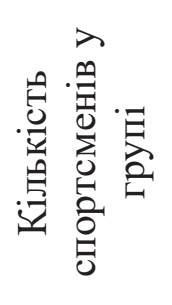 & 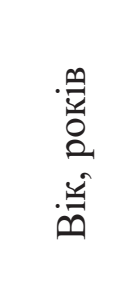 & 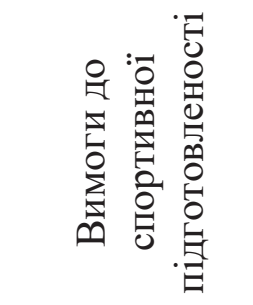 & 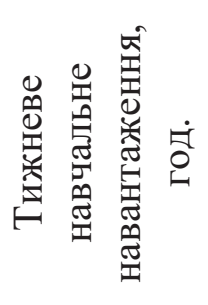 \\
\hline \multirow{4}{*}{$\begin{array}{l}\text { Попередньої } \\
\text { базової } \\
\text { підготовки }\end{array}$} & 1 & 8 & $13-14$ & III юн.-II юн. & 12 \\
\hline & 2 & 8 & $14-15$ & II юн.-І юн. & 14 \\
\hline & 3 & 7 & $15-16$ & I юн.-III & 18 \\
\hline & $\begin{array}{c}\text { Більше } 3 \\
\text { років }\end{array}$ & 6 & $16-17$ & III-II & 20 \\
\hline
\end{tabular}




\section{СЛОБОЖАНСЬКИЙ НАУКОВО-СПОРТИВНИЙ ВІСНИК}

Розроблена програма навчально-тренувального процесу легкоатлеток упродовж першого макроциклу підготовки складалась з програми чотирьох мезоциклів. У свою чергу програма кожного мезоциклу складалась з програми чотирьох тижневих мікроциклів. Програма i II мікроциклу була схожою, так само як і програма III і IV мікроциклу кожного мезоциклу. Засоби однакові, але тривалість (кількість підходів і серій) та інтенсивність роботи у II мікроциклі більше, ніж у I, так само у IV мікроциклі більше, ніж у III.

У мікроциклах першого втягуючого мезоциклу запланована мала і середня величина навантаження. У невеликому об'ємі передбачені спеціально-підготовчі вправи, спрямовані на розвиток різних видів витривалості: швидкісної, силової, стрибкової. Заплановано розвиток швидкісних, швидкісно-силових, координаційних здібностей і гнучкості. Бігова робота представлена човниковим бігом 3×60 м, прискореннями від 20 до 50 м, стартами з обтяженням 4-6х20 м, інтервальним бігом на дистанції від 50 до 150 м дві чи три серії з інтенсивністю (80-85 \%). Упродовж мезоциклу об'єм бігової роботи збільшується від 2000 м до 3000 м. Допоміжна фізична підготовка спринтерів представлена різноманітними стрибковими і силовими вправами, а також спеціальними вправами бар'єристів. Крім фізичної підготовки передбачено різнобічну технічну підготовку: оволодіння технікою спеціально-підготовчих вправ зі спринтерського і бар'єрного бігу, стрибків у довжину. Стосовно психологічної підготовки, то особлива увага приділялась формуванню мотивації спортсменок до систематичних занять у гуртку з легкої атлетики.

У другому втягуючому мезоциклі заплановано невеликі об'єми роботи, спрямованої на розвиток аеробної витривалості. Тому що виконання великих об'ємів аеробної роботи у спринтерів у підготовчому періоді негативно впливає на швидкісну техніку і прояв швидкісних здібностей (В. М. Платонов, 1984). Упродовж мезоциклу спостерігається тенденція до збільшення об'єму бігової роботи (прискорення від 30 до 60 м, старти з опором 4×20 м, біг в упорі 6×20 с і 6×10 с, бар'єрний біг 30-60 м, інтервальний біг на дистанції від 70 до 250 м з інтенсивністю 85-90 \% тощо), спрямованої на розвиток швидкісних здібностей і швидкісної витривалості. Так, об'єм спеціальної бігової роботи спортсменок збільшується від 2250 м до 3500 м. Збільшується також об'єм швидкісносилової роботи для зміцнення м'язів ніг і стопи (різноманітні стрибки, багатоскоки, стрибкові комплекси тощо). Крім того збільшується об'єм силової роботи зі штангою (12 кг): стрибки, випади, жим штанги лежачи тощо.

В ударних мікроциклах легкоатлетки у понеділок виконували значні об'єми бігової роботи анаеробного спрямування, тому у середу бігова робота не планувалась, а передбачено силову роботу, спрямовану на розвиток абсолютної сили, силової і стрибкової витривалості. У п'ятницю знову передбачено значні об'єми бігової роботи.

Базовий мезоцикл передбачає розвиток швидкісних і швидкісно-силових здібностей, абсолютної сили, силової, стрибкової і спеціальної швидкісної витривалості; удосконалення координаційної структури рухів у гладкому і бар'єрному бігу спортсменок (технічна підготовка). Бігова робота легкоатлеток починає набувати спеціального характеру. Об'єм спеціальної бігової роботи легко- атлеток збільшується від 2350 м до 3000 м, але він менший, ніж у попередньому мезоциклі.

У перших двох мікроциклах (втягуючому і ударному) тільки у понеділок легкоатлетки виконують значні об'єми спеціальної бігової роботи, спрямованої на розвиток швидкісних здібностей і швидкісної витривалості. Вказана робота вимагає глибокого використання енергетичних ресурсів організму і період відновлення може затягнутися до декількох днів. Після таких занять спостерігається значне пригнічення швидкісних здібностей, тому у середу заплановано силову підготовку в тренажерному залі для розвитку абсолютної сили і силової витривалості спортсменок. У п'ятницю легкоатлетки мають відновне заняття $з$ малим навантаженням (гра у баскетбол, масаж).

У третьому мікроциклі (ударному) у понеділок легкоатлетки виконують велике навантаження швидкісно-силового спрямування (інтервальний біг 2 серії 60+80+100 м з інтенсивністю 85-90\%; стрибковий комплекс: 4×20 м стрибки на правій нозі і 4×20 м стрибки на лівій нозі; біг $4 \times 100$ м 3 автопокришкою). У середу величина навантаження зменшується і змінюється його спрямованість навантаження - розвиток силової витривалості у тренажерному залі. У п'ятницю легкоатлетки виконують навантаження, спрямоване на розвиток швидкісної і загальної витривалості (перемінний біг серіями 1 хв. ( 400 м) і 2 хв. ( 300 м) 2 повторення 2 серії; крос 2500-3000 м).

У четвертому мікроциклі (відновному) запланована середня і мала величина навантаження, об'єм тренувальної роботи у порівнянні з ударним мікроциклом зменшений, широко застосовуються засоби активного відпочинку.

Отже, складаючи програму тренувань кожного мікроциклу, було враховано вплив на організм юних спортсменів занять з різними за величиною і спрямованістю навантаженнями, а також тривалість процесів відновлення після них. Такої ж думки у процесі побудови програм мікроциклів дотримуються провідні фахівці теорії і методики спорту (Л. П. Матвєєв, 1977; В. М. Платонов, 1987; В. М. Платонов, Ф.П.Суслов, 1995; Ю. М. Шкребтій, 1976 та інші).

3 грудня місця починається змагальний мезоцикл. У даному мезоциклі зменшується об'єм силової роботи $з$ обтяженням (гриф, штанга, гантелі тощо), проте, збільшується об'єм швидкісно-силової роботи з вагою власного тіла (багатоскоки, стрибки у глибину, стрибки на одні нозі тощо). Інтенсивність виконання спеціальних бігових вправ досягає максимальних величин (90-96 \%). Спостерігається тенденція до зменшення об'єму спеціальної бігової роботи від 3100 до 2550 м. Продовжується технічне удосконалення координаційної структури гладкого і бар'єрного бігу. Спортсменки продовжують здійснювати різнобічну технічну підготовку, оволодіваючи технікою спеціально-підготовчих вправ зі спринтерського і бар'єрного бігу, стрибків у довжину. Вирішуються завдання загальної і спеціальної психологічної підготовки легкоатлеток.

З метою визначення ефективності розробленої програми тренувального процесу легкоатлеток упродовж першого макроциклу «здвоєного» циклу річної підготовки, здійснювався порівняльний аналіз статистичних показників фізичної підготовленості спортсменок на початку і по завершенню макроциклу (табл. 4). 
Порівняння показників фізичної підготовленості легкоатлеток на початку і по завершенню макроциклу $(n=10)$

\begin{tabular}{|c|c|c|c|c|c|}
\hline \multirow{2}{*}{$\begin{array}{c}\text { № } \\
\text { 3/п }\end{array}$} & Тести & \multicolumn{2}{|c|}{$\mathrm{X} \pm \mathrm{m}$} & \multicolumn{2}{c|}{ Оцінка імовірності } \\
\cline { 3 - 6 } & Бересень & грудень & $\mathrm{t}$ & $\mathrm{P}$ \\
\hline 1 & Біг на 30 м зі старту, с & $5,18 \pm 0,06$ & $4,98 \pm 0,05$ & 2,56 & $<0,05$ \\
\hline 2 & Біг на 60 м зі старту, с & $9,73 \pm 0,07$ & $9,50 \pm 0,09$ & 2,09 & $>0,05$ \\
\hline 3 & Біг на 100 м зі старту, с & $15,55 \pm 0,06$ & $15,38 \pm 0,06$ & 2,00 & $>0,05$ \\
\hline 4 & Біг на 200 м зі старту, с & $33,89 \pm 0,19$ & $32,17 \pm 0,32$ & 4,62 & $<0,001$ \\
\hline 5 & Біг на 300 м зі старту, с & $55,2 \pm 0,38$ & $53,8 \pm 0,42$ & 2,47 & $<0,05$ \\
\hline 6 & $\begin{array}{l}\text { Стрибок у довжину } 3 \\
\text { місця, см }\end{array}$ & $186,2 \pm 2,33$ & $200,3 \pm 2,73$ & 3,93 & $<0,01$ \\
\hline
\end{tabular}

Виявлено загальну тенденцію до покращення статистичних показників фізичної підготовленості легкоатлеток. Достовірне $(\mathrm{P}<0,05)$ зростання результатів виявлено з бігу на 30 м на 3,86\% ( $t=2,56)$, бігу на 200 м - на 5,07\% ( $t=4,62)$, бігу на 300 м - на 2,17\% (t=2,47) і стрибках у довжину 3 місця - на 7,57\% (t=3,93). Отримані дані свідчать, що у легкоатлеток під впливом розробленої програми тренувань упродовж першого макроциклу підготовки відбулося суттєве покращення показників швидкісних здібностей, швидкісної витривалості і вибухової сили.

Недостовірне $(\mathrm{P}>0,05)$ зростання результатів легкоатлеток виявлено з бігу на 60 м на 2,36\% $(\mathrm{t}=2,09)$ і бігу на 100 м - на 1,09\% ( $\mathrm{t}=2,00)$. При цьому розрахункове значення t-критерію Ст'юдента у вказаних тестах несуттєво нижче критичного значення (tкр=2,28).

\section{Висновки / Дискусія}

Недостовірне зростання результатів з бігу на 60 м і на 100 м зі старту у легкоатлеток можна обгрунтувати даними досліджень провідних фахівців з теорії і методики фізичного виховання та спорту. Так, вказані тести дають змогу оцінити прояв швидкості у цілісній руховій дії, що включає швидкість простої рухової реакції, частоту рухів, швидкість поодиноких циклічних рухів, швидкий початок руху. У свою чергу швидкість простої рухової реакції мало піддається тренуванню, що зумовлено генотипом (Б. М. Шиян, 2010). Частота рухів має значний річний приріст у дівчат 11-12 років, а з 13 до 16 років річний приріст уповільнюється (Л. В. Волков, 1998).

Водночас ми погоджуємось з думкою Л. В. Волкова [3], який стверджує, що високі темпи приросту швидкості у цілісних рухових діях спостерігаються у юних спортсменок з 11-12 до 14-15 років. Під час нашого дослідження цілеспрямована швидкісна підготовка легкоатлеток 13-14 років здійснювалась лише у базовому і змагальному мезоциклах. Другий макроцикл «здвоєного» річного циклу підготовки легкоатлеток більш тривалий і передбачає планування більшого об'єму швидкісної підготовки, у порівнянні з першим макроциклом.

Визначено, що у легкоатлетів на етапі попередньої базової підготовки застосовується двоциклове планування річної підготовки («здвоєний» цикл). У структурі планування тренувального процесу упродовж першого макроциклу підготовки легкоатлетів виділяють два періоди: підготовчий і зимовий змагальний; три етапи: загально-підготовчий, спеціально-підготовчий і змагальний; чотири мезоцикли: два втягуючі, базовий і змагальний. Визначено головне завдання першого мароциклу - створення функціонального фундаменту для тренувань упродовж року та участь у змаганнях зимового змагального періоду.

Доведено ефективність програми навчально-тренувального процесу легкоатлеток упродовж першого макроциклу «здвоєного» циклу річної підготовки за наступними критеріями:

а) за спортивними досягненнями спортсменок під час участі у головних змаганнях макроциклу - відкритий Чемпіонат Черкаської області 3 легкоатлетичного двоборства серед юнаків і дівчат 2005-2006 років народження. За підсумками змагань одна спортсменка зайняла I місце з бігу на 60 м з бар'єрами + 60 м, інша - II місце з бігу на 60 м з бар'єрами + 400 м, і третя - V місце з бігу на 60 м з бар'єрами + 60 м. Отже, з десяти спортсменок, які брали участь в експерименті, одна легкоатлетка стала переможцем змагань, одна - призером, а інша зайняла п'яте місце;

б) на основі достовірного $(\mathrm{P}<0,05)$ покращення статистичних показників фізичної підготовленості (швидкісні здібності, швидкісна витривалість і вибухова сила) легкоатлеток упродовж експерименту. Так, результати 3 бігу на 30 м зросли на 3,86\% (t=2,56), бігу на 200 м - на $5,07 \%(t=4,62)$, бігу на 300 м - на 2,17\% (t=2,47) і стрибках у довжину з місця - на 7,57\% (t=3,93).

Перспективи подальших досліджень. Передбачається розробка програми тренувального процесу легкоатлеток-спринтерів 13-14 років упродовж другого макроциклу «здвоєного» циклу річної підготовки. 


\section{СЛОБОЖАНСЬКИЙ НАУКОВО-СПОРТИВНИЙ ВІСНИК}

Конфлікт інтересів. Автори заявляють, що відсутній конфлікт інтересів, який може сприйматись таким, що може завдати шкоди неупередженості статті.

Джерела фінансування. Ця стаття не отримала фінансової підтримки від державної, громадської або комерційної організації.

\section{Список посилань}

1. Бобровник В. І., Совенко С. П., Колот А. В. (2019), Легка атлетика: навчальна програма для дитячо-юнацьких спортивних шкіл, спеціалізованих дитячо-юнацьких спортивних шкіл олімпійського резерву, шкіл вищої спортивної майстерності та спеціалізованих навчальних закладів спортивного профілю, Київ: Логос, URL: http://uaf.org.ua/images/doc/books/Programa_DUSCH.pdf.

2. Висоцька О. М., Сергієнк, В. М. (2014), «Показники розвитку швидкісно-силових здібностей юних бігунів», Сучасні проблеми фізичного виховання і спорту різних груп населення : матеріали XIV Міжнар. наук.-практ. конф. молодих учених, Суми, Т. 2, С. $254-258$.

3. Волков Л. В. (2002), Теория и методика детского и юношеского спорта, Киев: Олимпийская литература, 252 с.

4. Вродзинський М. О., Дорофєєва, Т. І., Коробейнік В. А. (2018), «Вплив засобів загальної фізичної підготовки на розвиток швидкісних здібностей у хлопців та дівчат на етапі початкової підготовки в легкій атлетиці», Здоровье, спорт, реабилитация, № 1 , С. 118-126.

5. Врублевський Є. П. (2011), «Теоретико-методичне обґрунтування програмування макроциклу підготовки спортсменок, що спеціалізуються в швидкісно-силових видах легкої атлетики», Слобожанський науково-спортивний вісник, № 4(27), С. 74-77.

6. Добринський В., Мудрик Ж. (2012), «Підвищення фізичної підготовки юних легкоатлетів за допомогою бар'єрних вправ», Фізичне виховання, спорт і культура здоров’я у сучасному суспільстві, № 4(20), С. 422-425.

7. Маленюк Т. В. (2014), «Вплив тренувального навантаження на розвиток рухових здібностей юних легкоатлетів 12-13 років», Слобожанський науково-спортивний вісник, № 1(39), С. 58-61.

8. Маленюк Т. В. (2017), «Індивідуальна програма бігової роботи легкоатлеток-стаєрів на заняттях підвищення спортивної майстерності при підготовці до кросового сезону», Слобожанський науково-спортивний вісник, № 5(61), С. 69-74.

9. Матвеев Л. П. (1999), Основы общей теории спорта и системы подготовки спортсменов, Киев: Олимпийская литература, 456 c.

10. Микич М. С. (2005), Система спортивної підготовки легкоатлетів: сучасний погляд, Львів: Львівський державний інститут фізичної культури, 125 с.

11. Платонов В. Н. (1997), Общая теория подготовки спортсменов в олимпийском спорте, Киев: Олимпийская литератуpa, $453 \mathrm{c}$

12. Трухан Л. В. (2013), «Проблеми спортивної підготовки легкоатлетів: сучасний погляд», Вісник Житомирського державного університету, Вип. 4(70), С. 104-110.

Стаття надійшла до редакції: 27.11.2020 р.

Опубліковано: 21.12.2020 p.

Аннотация. Татьяна Маленюк, Виктория Бабалич, Галина Панченко, Александр Брояковский. Эффективность программы учебно-тренировочного процесса юных легкоатлеток 13-14 лет в течение первого макроцикла годичной подготовки (на примере спринтерского бега). Цель: разработать и доказать эффективность программы тренировочного процесса легкоатлеток-спринтеров в течение первого макроцикла годичной подготовки. Материал и методы: к эксперименту были привлечены десять спортсменок 13-14 лет, которые тренируются в секции легкой атлетики опорного учебного заведения. Использованы следующие методы исследования: теоретический анализ и обобщение данных научно-методической литературы, педагогический эксперимент, педагогическое тестирование, методы математической статистики. Результаты: определено, что у легкоатлетов на этапе предварительной базовой подготовки применяется двуцикловое планирование годичной подготовки («сдвоенный» цикл). Раскрыта структура планирования тренировочного процесса в первом макроцикле: периоды, этапы, мезоцикли. Разработана программа тренировочного процесса легкоатлеток в течение первого макроцикла «сдвоенного» цикла годичной подготовки. Выводы: доказана эффективность программы тренировочного процесса легкоатлеток на основе повышения их показателей физической подготовленности и спортивных достижений на соревнованиях по легкоатлетическомудвоеборью.

Ключевые слова: легкая атлетика, программа, макроцикл, физическая подготовленность, юные спринтеры.

Abstract. Tetiana Maleniuk, Viktoriia Babalich, Halyna Panchenko, Oleksandr Broiakovskyi. Effectiveness of the education and training process program for athletes 13-14 years old during the first macrocycle of on annual training (on the example of sprint running). Purpose: to develop and prove the effectiveness of the training process program for athletes-sprinters during the first macrocycle of an annual training. Material and methods: the experiment involved ten athletes, ranged from 13-14 years old who train in the athletics section of secondary educational institution. The following research methods were used: theoretical analysis and generalization of scientific and methodological literature data, pedagogical experiment, pedagogical testing and methods of mathematical statistics. Results: it was determined that athletes at the stage of preliminary basic training use two-cycle planning of an annual training ("double" cycle). The structure of planning the training process in the first macrocycle is revealed on periods, stages, mesocycles. The program of the training process of athletes during the first macrocycle of the "double" cycle of an annual training is developed. Conclusions: the effectiveness of the training process program among athletes was proved on the basis of increasing their physical preparedness and sports achievements in the track and field athletics competitions.

Keywords: athletics, program, macrocycle, physical strength, young sprinters.

Маленюк, Т., Бабаліч, В., Панченко, Г., Брояковський, О. (2020), «Ефективність програми навчально-тренувального процесу юних легкоатлеток 13-14 років упродовж першого макроциклу річної підготовки (на прикладі спринтерського бігу)» doi:10.15391/snsv.2020-6.006 


\section{References}

1. Bobrovnyk, V. I., Sovenko, S. P., Kolot, A. V. (2019), Lehka atletyka. Navchalna prohrama dlia dytiacho-yunatskykh sportyvnykh shkil, spetsializovanykh dytiacho-yunatskykh sportyvnykh shkil olimpiiskoho rezervu, shkil vyshchoi sportyvnoi maisternosti ta spetsializovanykh navchalnykh zakladiv sportyvnoho profiliu [Track-and-field. An on-line tutorial is for child-youth sporting schools, specialized child-youth sporting schools of olympic reserve, schools of higher sporting mastery and specialized educational establishments of sporting profile], Kyiv: Lohos, URL: http://uaf.org.ua/images/doc/books/Programa_DUSCH.pdf (in Ukr.)

2. Vysotska, O. M., Serhiienko, V. M. (2014), «Indexes of developing speed-power flairs of young runners», Suchasni problemy fizychnoho vykhovannia i sportu riznykh hrup naselennia: materialy KhIV Mizhnar. nauk.-prakt. konf. molodykh uchenykh, Sumy, T. 2. pp. 254-258 (in Ukr.)

3. Volkov, L. V. (2002), Teoriia i metodika detskogo i iunosheskogo sporta [The theory and methodology of child's and youth sport], Kiev: Olimpiiskaia literatura, 252 p. (in Russ.)

4. Vrodzynskyi, M. O., Dorofieieva, T. I., Korobeinik, V. A. (2018), «Influence of facilities of body-conditioning on developing speed flairs for guys and girls on the stage of initial preparation in track-and-field», Zdorove, sport, reabylytatsyia, № 1, pp. 118-126 (in Ukr.)

5. Vrublevskyi, Ye. P. (2011), «Theoretical and methodical ground of programming of macrocycle of preparation of sportswomen that is specialized in the speed-power types of track-and-field", Slobozhanskyi naukovo-sportyvnyi visnyk, No.4 (27), pp. 74-77 (in Ukr.)

6. Dobrynskyi, V., Mudryk, Zh. (2012), "An increase of physical preparation of young athletes is by means of barrier exercises», Fizychne vykhovannia, sport i kultura zdorovia u suchasnomu suspilstvi, No. 4(20), pp. 422-425 (in Ukr.)

7. Maleniuk, T. V. (2014), «Influence of the training loading on developing motive flairs of young athletes 12-13», Slobozhanskyi naukovo-sportyvnyi visnyk, No. 1 (39), pp. 58-61 (in Ukr.)

8. Maleniuk, T. V. (2017), «Individual program of running activity of track-and-field athletes during training sessions to improve sport skills in the preparation for a cross season", Slobozhanskyi naukovo-sportyvnyi visnyk, No. 5 (61), pp. $69-74$ (in Ukr.)

9. Matveev, L. P. (1999), Osnovy obshchei teorii sporta i sistemy podgotovki sportsmenov [Bases of general theory of sport and system of preparation of sportsmen], Kiev: Olimpiiskaia literatura, 456 p. (in Russ.)

10. Mykych, M. S. (2005), Systema sportyvnoi pidhotovky lehkoatletiv : suchasnyi pohliad [System of sporting preparation of athletes: modern look], Lviv: Lvivskyi derzhavnyi instytut fizychnoi kultury, 125 p. (in Ukr.)

11. Platonov, V. N. (1997), Obshchaia teoriia podgotovki sportsmenov v olimpiiskom sporte [A general theory of preparation of sportsmen is in olympic sport], Kiev: Olimpiiskaia literatura, 453 p. (in Russ.)

12. Trukhan, L. V. (2013), «Problems of sporting preparation of athletes : modern look», Visnyk Zhytomyrskoho derzhavnoho universytetu, Vyp. 4(70), pp. 104-110 (in Ukr.)

Received: 27.11.2020.

Published: 21.12.2020.

\section{Відомості про авторів / Information about the Authors}

Маленюк Тетяна Володимирівна: к. фіз.вих., доцент; Центральноукраїнський державний педагогічний університет імені Володимира Винниченка: вул. Шевченка 1, м. Кропивницький, 25009, україна.

Маленюк Татьяна Владимировна: к.физ.восп., доцент; Центральноукраинский государственный педагогический университет имени Владимира Винниченка: ул. Шевченко 1, г. Кропивницкий, 25009, Украина.

Tetiana Maleniuk: PhD (Physical Education and Sport), Associate Professor; Central Ukrainian state pedagogical university name Volodimir Vinnichenko: Shevchenko str. 1, Kropyvnytskyi, 25009, Ukraine.

ORCID.ORG/0000-0003-2966-1382

E-mail: tmaleniuk@gmail.com

Бабаліч Вікторія Анатоліївна: к.пед.н., доцент; Центральноукраїнський державний педагогічний університет імені Володимира Винниченка: вул. Шевченка 1, м. Кропивницький, 25009, Україна.

Бабалич Виктория Анатольевна: к.пед.н., доцент; Центральноукраинский государственный педагогический университет имени Владимира Винниченка: ул. Шевченко 1, г. Кропивницкий, 25009, Украина.

Viktoriia Babalich: PhD (Pedagogical), Associate Professor; Central Ukrainian state pedagogical university name Volodimir Vinnichenko: Shevchenko str. 1, Kropyvnytskyi, 25009, Ukraine.

ORCID.ORG/0000-0001-5698-836X

E-mail: vikababalich@meta.ua

Панченко Галина Іванівна: к.пед.н., старший викладач; Центральноукраїнський державний педагогічний університет імені Володимира Винниченка: вул. Шевченка 1, м. Кропивницький, 25009, україна.

Панченко Галина Ивановна: к.пед.н., старший преподаватель; Центральноукраинский государственный педагогический университет имени Владимира Винниченка: ул. Шевченко 1, г. Кропивницкий, 25009, Украина.

Halyna Panchenko: PhD (Pedagogical), senior teacher; Central Ukrainian state pedagogical university name Volodimir Vinnichenko: Shevchenko str. 1, Kropyvnytskyi, 25009, Ukraine.

ORCID.ORG/0000-0003-2024-2202

E-mail: gp28@meta.ua

Брояковський Олександр Вікторович: к.пед.н., старший викладач; Центральноукраїнський державний педагогічний університет імені Володимира Винниченка: вул. Шевченка 1, м. Кропивницький, 25009, Україна.

Брояковский Александр Викторович: к.пед.н., старший преподаватель; Центральноукраинский государственный педагогический университет имени Владимира Винниченка: ул. Шевченко 1, г. Кропивницкий, 25009, Украина.

Oleksandr Broiakovskyi: PhD (Pedagogical), senior teacher; Central Ukrainian state pedagogical university name Volodimir Vinnichenko: Shevchenko str. 1, Kropyvnytskyi, 25009, Ukraine.

ORCID.ORG/0000-0002-2625-7088

E-mail: a.broyakovsky@mail.ru 


\title{
Вплив використання спеціальних вправ на психофізіологічні показники юних боксерів 15-16 років
}

\author{
Юрій Шестак \\ Вячеслав Мулик \\ Дар'я Окунь
}

Харківська державна академія фізичної культури, Харків, Україна

\begin{abstract}
Мета: визначити ефективність застосування спеціальних вправ з використанням боксерських споряджень протягом річного макроциклу у юних боксерів 15-16 років.

Матеріал і методи: дослідження проводилися із залученням юних боксерів 15-16 років, що склали контрольну (12 спортсменів) і експериментальну (12 спортсменів) групи, які здійснювали річний тренувальний процес за програмою ДЮСШ, але в експериментальній групі в кінці кожного тренування використовувалися вправи із застосуванням боксерських споряджень (вправи з мішком і грушею; з настінною подушкою; пневматичною грушею; вправи з м'ячем на гумках; вправи з малим підвісним м'ячем). Початкове і прикінцеве вимірювання психофізіологічних показників здійснювалося після тренування з великим навантаженням, яке використовувалося у боксерів обох груп.

Результати: отримані результати дозволяють розширити методику використання спеціальних вправ для розвитку швидкісно-силових якостей відповідно до специфіки виду спорту. Визначено доцільність використання вправ спеціальної швидкісно-силової спрямованості у юних боксерів 15-16 років наприкінці тренувального заняття на фоні втоми.

Висновки: підтверджено покращення результатів психофізіологічних показників, які є складовими рухової діяльності боксерів (часу простої реакції на звук і світло; проби Ромберга, показників тесту Шульте, концентрації та переключення уваги за тестом Бурдона).
\end{abstract}

Ключові слова: юні боксери, психофізіологічні показники, спеціальні боксерські спорядження, швидкісно-силові якості.

\section{Вступ}

Фізична підготовка боксера $є$ основним чинником, що забезпечує якість технічної, тактичної та психологічної підготовленості, рівень розвитку всіх інших компонентів майстерності $[1 ; 4 ; 15]$.

Методика розвитку швидкісно-силових якостей пов'язується із забезпеченням необхідної функціональної підготовки організму для вдосконалення техніко-тактичної майстерності і планомірного підвищення швидкості виконання змагальної вправи. Спеціальні дослідження $[2 ; 10 ; 14]$ свідчать про неузгодженість думок тренерів у різних видах спорту щодо тренувального впливу найбільш популярних засобів спеціальної фізичної підготовки (СФП). Очевидно, причина такого становища криється в нестачі знань про фізіологічні механізми, що лежать в основі спеціальної працездатності спортсмена і засобів, що визначають тренувальний ефект [3; 6; 7].

Сьогодні спортсмени широко використовують у тренуванні змагальні вправи з високою інтенсивністю зусиль [8]. Поряд з іншими і не менш важливими перевагами такий прийом виступає як вельми ефективний засіб СФП, бо важко придумати що-небудь більш спеціальне у цьому відношенні. Тому виконання змагальної вправи у тренуванні з максимальною інтенсивністю зусиль і високою швидкістю є важливим засобом системи СФП, але вимагає наукового і методичного обґрунтування [13].

За ступенем відповідності режиму роботи організму при виконанні змагальної вправи має сенс виділити три групи засобів СФП [12; 18]: специфічні - різні форми (варіанти) виконання основної спортивної вправи із завданням пристосування організму до режиму його роботи в умовах змагань; спеціалізовані - адекватні до змагальних умов за найбільш істотними руховими і функціональними параметрами режиму роботи організму; неспецифічні - формально не відповідають змагальній вправі за руховою організацією, але які сприятимуть розвитку функціональних можливостей організму в потрібному напрямку; їх завдання полягає в посиленні тренувального ефекту спеціалізованих засобів за рахунок додаткового вибіркового впливу на ті чи інші фізіологічні системи і функції організму.

Практично при підборі засобів СФП слід керуватися принципом динамічної відповідності [5; 9; 17], згідно з яким вони повинні бути адекватні змагальній вправі за наступними критеріями: групам м'язів, що залучаються до роботи, амплітуда і напрям руху; акцентована ділян- 